\title{
Sistem Pendukung Keputusan Pemilihan Mahasiswa Berprestasi di STMIK Atma Luhur Pangkalpinang dengan Menggunakan Metode Analytical Hierarchy Process (AHP)
}

\author{
Fitriyani \\ Program Studi Sistem Informasi, STMIK Atma Luhur Pangkalpinang \\ (Corresponding author) bilalzakwan12@yahoo.com
}

\begin{abstract}
The selection and determination of the best students to be a long and complicated process. The electoral process is a lot of opportunities to make the wrong decision moreover just see the criteria as done until now. A college should take the right decision, if this is done properly will guarantee a selection of outstanding students, it can use a decision-making method is the method of Analytical Hierarchy Process (AHP) for weighting criteria and alternatives. In this study, to obtain the solution of decision-making selection of outstanding students need to establish some criteria and alternatives. To assist in the selection of outstanding students using Analytical Hierarchy Process (AHP) that will help the computing process AHP, besides Decision Support System is useful to process the data selection of outstanding students college level (Academic).
\end{abstract}

Keywords: Analytical Hierarchy Process (AHP), Selection of Student Achievement, Decision Support System

Intisari - Pemilihan dan penetapan mahasiswa berprestasi menjadi suatu proses yang lama dan rumit. Proses pemilihan tersebut banyak terdapat peluang untuk membuat keputusan yang salah apalagi hanya melihat satu kriteria seperti yang pernah dilakukan sampai sekarang. Sebuah perguruan tinggi harus mengambil keputusan yang tepat, bila hal ini dilakukan dengan baik dan benar akan menjamin hasil pemilihan mahasiswa berprestasi tersebut, maka dapat menggunakan metode pengambilan keputusan yaitu metode Analytical Hierarchy Process (AHP) untuk pembobotan kriteria dan alternatif. Dalam penelitian ini, untuk mendapatkan solusi pengambilan keputusan pemilihan mahasiswa berprestasi perlu disusun beberapa kriteria dan alternatif. Untuk membantu proses pemilihan mahasiswa berprestasi dengan menggunakan metode Analytical Hierarchy Process (AHP) sehingga akan membantu proses komputasi AHP, selain itu Sistem Pendukung Keputusan berguna untuk mengolah data-data pemilihan mahasiswa berprestasi tingkat perguruan tinggi (Akademik).

Kata Kunci : Analytical Hierarchy Process (AHP), Pemilihan Mahasiswa Berprestasi, Sistem Pendukung Keputusan

\section{A. Latar Belakang}

I. PENDAHULUAN

Perkembangan yang pesat tidak hanya teknologi perangkat keras dan perangkat lunak saja, tetapi metode komputasi juga ikut berkembang. Salah satu metode komputasi yang cukup berkembang saat ini adalah metode sistem pengambilan keputusan (Decision Support System).

Dalam persaingan dunia kerja, dibutuhkan lulusan yang memiliki kemampuan hard skills dan soft skills yang seimbang, sehingga mahasiswa dituntut untuk aktif dan memiliki prestasi di bidang akademik dan non akademik. Oleh karena itu, di setiap perguruan tinggi perlu diidentifikasi mahasiswa yang dapat melakukan keduanya dan diberikan penghargaan sebagai mahasiswa yang berprestasi.

Proses pemilihan mahasiswa berprestasi merupakan permasalahan yang melibatkan banyak kriteria yang dinilai, sehingga dalam penyelesaiannya diperlukan sistem pendukung keputusan dengan multikriteria. Salah satu metode sistem pendukung keputusan yang multikriteria adalah Analytical Hierarchy Process(AHP). 
Pada penelitian pemilihan mahasiswa berprestasi yang dilakukan STMIK Atma Luhur Pangkalpinang masih terdapat kendala yaitu hanya menggunakan satu kriteria yaitu IPK sehingga hanya melihat dari segi akademik saja.

Untuk memecahkan permasalahn tersebut, maka dibuat Sistem Pendukung Keputusan Pemilihan Mahasiswa Berprestasi menggunakan metode AHP.

B. Rumusan Masalah

1. Bagaimana metode AHP dapat memberikan solusi dalam permasalahan pemilihan mahasiswa berprestasi di STMIK ATMA LUHUR?

2. Bagaimana model sistem pendukung keputusan pemilihan mahasiswa berprestasi yang berbasis komputer dengan menggunakan metode AHP?

\section{LANDASAN TEORI}

A. Konsep dasar Sistem Penunjang Keputusan

Definisi sistem adalah sekumpulan hal atau kegiatan atau elemen atau subsistem yang saling bekerja sama atau yang dihubungkan dengan cara-cara tertentu sehingga membentuk satu kesatuan untuk melaksanakan suatu fungsi guna mencapai suatu tujuan.

Secara umum, sistem pendukung keputusan adalah sistem berbasis komputer yang interaktif, yang membantu pengambil keputusan memanfaatkan data dan model untuk menyelesaikan masalah-masalah yang tak terstruktur dan semi terstruktur.[3]

\section{B. Analytical Hierarchy Process}

Metode Analytical Hierarchy Process (AHP) dikembangkan awal tahun 1970-an oleh Thomas L. Saaty, seorang ahli matematika dari Universitas Pittsburg. Analisis ini ditujukan untuk membuat suatu model permasalahan yang tidak mempunyai struktur, biasanya ditetapkan untuk masalah yang terukur (kuantitatif), masalah yang memerlukan pendapat (judgement) maupun pada situasi yang kompleks atau tidak terkerangka, pada situasi dimana data statistic sangat minim atau tidak ada sama sekali dan hanya bersifat kualitatif yang didasari oleh persepsi, pengalaman atau intuisi.[4]

Model AHP memakai persepsi manusia yang dianggap "expert" sebagai input utamanya. Kriteria "expert" disini bukan berarti bahwa orang tersebut haruslah jenius, pintar, bergelar doktor dan sebagainya tetapi lebih mengacu pada orang yang mengerti benar permasalahan yang dilakukan, merasakan akibat suatu masalah atau punya kepentingan terhadap masalah tersebut.

\section{Pengertian SPK}

Konsep Sistem Pendukung Keputusan pertama kali diperkenalkan pada awal tahun 1970-an oleh Michael S. Scott Morton dengan istilah Management Decision System (Sprague, 1982). Konsep pendukung keputusan ditandai dengan sistem interaktif berbasis komputer yang membantu pengambil keputusan memanfaatkan data dan model untuk menyelesaikan masalah-masalah yang tidak terstruktur. Pada dasarnya SPK dirancang untuk mendukung seluruh tahap pengambilan keputusan mulai dari mengidentifikasi masalah, memilih data yang relevan, menentukan pendekatan yang digunakan dalam proses pengambilan keputusan, sampai mengevaluasi pemilihan alternatif. Menurut Simon (Suryadi dan Ramdhani, 2002, h.15-16) model yang menggambarkan proses pengambilan keputusan. Proses ini terdiri dari tiga fase, yaitu sebagai berikut

1. Intelligence Tahap ini merupakan proses penelusuran dan pendeteksian dari lingkup problematika serta proses pengenalan masalah. Data masukan diperoleh, diproses, dan diuji dalam rangka mengindentifikasi masalah.

2. Design Tahap ini merupakan proses menemukan, mengembangkan, dan menganalisis alternatif tindakan yang bisa dilakukan. Tahap ini meliputi proses untuk mengerti masalah, menurunkan solusi dan menguji kelayakan solusi.

3. Choice Pada tahap ini dilakukan proses pemilihan diantara berbagai alternatif tindakan yang mungkin dijalankan. Hasil pemilihan tersebut kemudian diimplementasikan dalam proses pengambilan keputusan. Meskipun implementasi termasuk tahap ketiga, namun ada beberapa pihak berpendapat bahwa tahap ini perlu dipandang sebagai bagian yang terpisah guna menggambarkan hubungan antar fase secara lebih komprehensif. 
d. Karakteristik SPK

1. Sistem Pendukung Keputusan dirancang untuk membantu pengambil keputusan dalam memecahkan masalah yang sifatnya semi terstruktur ataupun tidak terstruktur dengan menambahkan kebijaksanaan manusia dan informasi komputerisasi.

2. Dalam proses pengolahannya, sistem pendukung keputusan mengkombinasikan penggunaan model-model analisis dengan teknik pemasukan data konvensional serta fungsi-fungsi pencari / interogasi informasi.

3. Sistem Pendukung Keputusan, dirancang sedemikian rupa sehingga dapat digunakan/dioperasikan dengan mudah.

4. Sistem Pendukung Keputusan dirancang dengan menekankan pada aspek fleksibilitas serta kemampuan adaptasi yang tinggi.

2. Penyelesaian AHP dengan software Expert Choice 2000

Expert Choice 2000 merupakan perangkat lunak yang dapat digunakan untuk perhitungan pemecahan persoalan dengan AHP sebagai expert choice. Pada penelitian ini, digunakan analisis dengan perhitungan aplikasi Expert Choice 2000. Tujuan dilakukan analisis ini adalah untuk membuktikan aplikasi Expert choice yang sudah teruji kehandalannya.expert choice 2000 menyediakan struktur untuk seluruh proses pengambilan keputusan, yaitu :[1]
a. Sebuah tool yang memfasilitasi kerjasama antara beberapa pihak yang berkepentingan
b. Analisis pengambilan keputusan
c. Meningkatkan komunikasi
d. Memberi keputusan yang lebih tepat
e. Dokumentasi proses pengambilan keputusan
f. Sebuah konsensus keputusan
g. Keputusan akhir yang lebih baik dan dapat dibenarkan

3. Komponen SPK

a. Data Management. Termasuk database, yang mengandung data yang relevan untuk berbagai situasi dan diatur oleh software yang disebut Database Management Systems (DBMS)

b. Model Management. Melibatkan model finansial, statistikal, management science, atau berbagai model kuantitatif lainnya, sehingga dapat memberikan ke sistem suatu kemampuan analitis, dan manajemen software yang diperlukan.

c. Commication (dialog subsystem). User dapat berkomunikasi dan memberikan perintah pada DSS melalui subsistem ini. Ini berarti menyediakan antarmuka.

d. Knowledge Management. Subsistem optional ini dapat mendukung subsistem lain atau bertindak sebagai komponen yang berdiri sendiri.

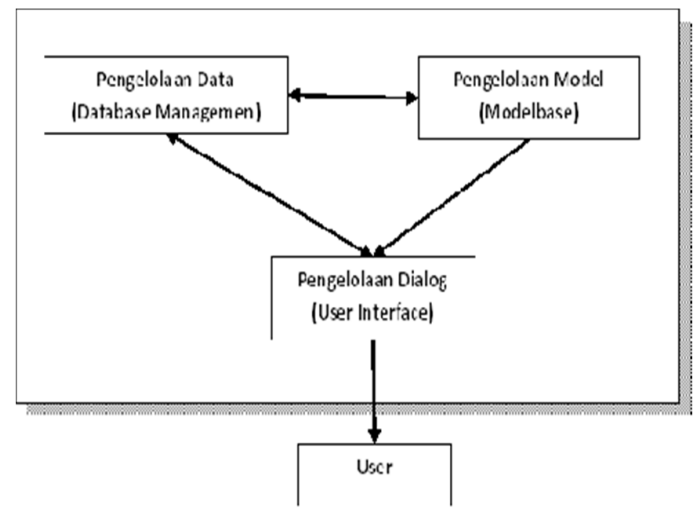

Gambar 1. Hubungan antara ketiga komponen SPK

\section{Tujuan SPK}

1.Memberikan dukungan untuk pembuatan keputusan pada masalah yang semi/tidak terstruktur.

2.Memberikan dukungan pembuatan keputusan kepada manajer pada semua tingkat dengan membantu integrasi antar tingkat. 
3.Meningkatkan efektifitas manajer dalam pembuatan keputusan dan bukan peningkatan efisiennya.

\section{G. Definisi Mahasiswa Berprestasi}

Mahasiswa berprestasi adalah mahasiswa yang berhasil mencapai prestasi tinggi, baik akademik maupun non akademik, mampu berkomunikasi dengan bahasa indonesia dan bahasa inggris, bersikap positif serta berjiwa Pancasila.[4]

Tujuan pemilihan mahasiswa berprestasi adalah :

a. memberikan penghargaan kepada mahasiswa yang berhasil mencapai prestasi tinggi

b. memberikan motivasi kepada mahasiswa untuk melaksanakan kegiatan kurikuler, ko-kurikuler dan ekstrakurikuler sebagai wahana mensinergikan hard skills dan soft skills mahasiswa

c. mendorong perguruan tinggi untuk mengembangkan iklim kehidupan kampus yang dapat menfasilitasi mahasiswa mencapai prestasi yang membanggakan secara berkesinambungan.

H. Tahapan SPK

Dalam metode AHP dilakukan langkah-langkah sebagai berikut :

a. Mendefinisikan masalah dan menentukan solusi yang diinginkan.

Dalam tahap ini kita berusaha menentukan masalah yang akan kita pecahkan secara jelas, detail dan mudah dipahami. Dari masalah yang ada kita coba tentukan solusi yang mungkin cocok bagi masalah tersebut. Solusi dari masalah mungkin berjumlah lebih dari satu. Solusi tersebut nantinya kita kembangkan lebih lanjut dalam tahap berikutnya.

b. Membuat struktur hierarki yang diawali dengan tujuan utama.

Setelah menyusun tujuan utama sebagai level teratas akan disusun level hirarki yang berada di bawahnya yaitu kriteria-kriteria yang cocok untuk mempertimbangkan atau menilai alternatif yang kita berikan dan menentukan alternatif tersebut. Tiap kriteria mempunyai intensitas yang berbeda-beda. Hirarki dilanjutkan dengan subkriteria (jika mungkin diperlukan).

c. Membuat matrik perbandingan berpasangan yang menggambarkan kontribusi relatif atau pengaruh setiap elemen terhadap tujuan atau kriteria yang setingkat di atasnya.

Matriks yang digunakan bersifat sederhana, memiliki kedudukan kuat untuk kerangka konsistensi, mendapatkan informasi lain yang mungkin dibutuhkan dengan semua perbandingan yang mungkin dan mampu menganalisis kepekaan prioritas secara keseluruhan untuk perubahan pertimbangan. Pendekatan dengan matriks mencerminkan aspek ganda dalam prioritas yaitu mendominasi dan didominasi. Perbandingan dilakukan berdasarkan judgment dari pengambil keputusan dengan menilai tingkat kepentingan suatu elemen dibandingkan elemen lainnya. Untuk memulai proses perbandingan berpasangan dipilih sebuah kriteria dari level paling atas hirarki misalnya $\mathrm{K}$ dan kemudian dari level di bawahnya diambil elemen yang akan dibandingkan misalnya E1,E2,E3,E4,E5.

d. Melakukan Mendefinisikan perbandingan berpasangan sehingga diperoleh jumlah penilaian seluruhnya sebanyak $n$ $x[(n-1) / 2]$ buah, dengan $n$ adalah banyaknya elemen yang dibandingkan.

Hasil perbandingan dari masing-masing elemen akan berupa angka dari 1 sampai 9 yang menunjukkan perbandingan tingkat kepentingan suatu elemen. Apabila suatu elemen dalam matriks dibandingkan dengan dirinya sendiri maka hasil perbandingan diberi nilai 1. Skala 9 telah terbukti dapat diterima dan bisa membedakan intensitas antar elemen. Hasil perbandingan tersebut diisikan pada sel yang bersesuaian dengan elemen yang dibandingkan. Skala perbandingan perbandingan berpasangan dan maknanya yang diperkenalkan oleh Saaty bisa dilihat di bawah.

Intensitas Kepentingan

1 = Kedua elemen sama pentingnya, Dua elemen mempunyai pengaruh yang sama besar

3 = Elemen yang satu sedikit lebih penting daripada elemen yanga lainnya, Pengalaman dan penilaian sedikit menyokong satu elemen dibandingkan elemen yang lainnya

5 = Elemen yang satu lebih penting daripada yang lainnya, Pengalaman dan penilaian sangat kuat menyokong satu elemen dibandingkan elemen yang lainnya 7 = Satu elemen jelas lebih mutlak penting daripada elemen lainnya, Satu elemen yang kuat disokong dan dominan terlihat dalam praktek.

9 = Satu elemen mutlak penting daripada elemen lainnya, Bukti yang mendukung elemen yang satu terhadap elemen lain memeliki tingkat penegasan tertinggi yang mungkin menguatkan. 
2,4,6,8 = Nilai-nilai antara dua nilai pertimbangan-pertimbangan yang berdekatan, Nilai ini diberikan bila ada dua kompromi di antara 2 pilihan Kebalikan = Jika untuk aktivitas i mendapat satu angka dibanding dengan aktivitas j , maka j mempunyai nilai kebalikannya dibanding dengan i

e. Menghitung nilai eigen dan menguji konsistensinya.

Jika tidak konsisten maka pengambilan data diulangi.

f. Mengulangi langkah 3,4, dan 5 untuk seluruh tingkat hirarki.

g. Menghitung vektor eigen dari setiap matriks perbandingan berpasangan

yang merupakan bobot setiap elemen untuk penentuan prioritas elemen-elemen pada tingkat hirarki terendah sampai mencapai tujuan. Penghitungan dilakukan lewat cara menjumlahkan nilai setiap kolom dari matriks, membagi setiap nilai dari kolom dengan total kolom yang bersangkutan untuk memperoleh normalisasi matriks, dan menjumlahkan nilai-nilai dari setiap baris dan membaginya dengan jumlah elemen untuk mendapatkan rata-rata.

h. Memeriksa konsistensi hirarki.

Yang diukur dalam AHP adalah rasio konsistensi dengan melihat index konsistensi. Konsistensi yang diharapkan adalah yang mendekati sempurna agar menghasilkan keputusan yang mendekati valid. Walaupun sulit untuk mencapai yang sempurna, rasio konsistensi diharapkan kurang dari atau sama dengan $10 \%$.

\section{METODOLOGI PENELITIAN}

\section{a. Jenis Penelitian}

Berdasarkan jenis informasi yang dikelola, jenis penelitian ini adalah Penelitian Kuantitatif, karena menggunakan pengukuran data dan statistik objektif melalui perhitungan ilmiah berasal dari sampel pihak akademik perguruan tinggi dengan memberikan jawaban atas sejumlah pertanyaan yang dituangkan ke dalam kuesioner menggunakan metode pendekatan Analytical Hierarchy Process (AHP) dan kemudian diuji menggunakan software Expert Choice 2000.

\section{b. Pemilihan Sampel}

Dalam memilih sampel, penulis mengambil data dari populasi yang terbatas dengan menggunakan purposes sampling, yaitu pengambilan sampel dilakukan atas dasar pertimbangan tertentu. Responden yang diambil dalam pemilihan sampel ini adalah responden ahli yang berasal dari pihak akadmeik. Disini penulis mengambil sampel sebanyak 3 orang dari total populasi. Dengan total populasi sebanyak 6 orang.

\section{c. Pengumpulan data}

Pengumpulan data penelitian dilakukan dengan cara pengisian kuisioner untuk memperoleh data sesuai dengan tujuan penelitian. Kuesioner dibagikan kepada pihak akademik perguruan tinggi yaitu Pembantu Ketua 1 Bidang Akademik, Pembantu Ketua 3 Bidang Kemahasiswaan, dan Ketua Pengurus Yayasan Atma Luhur.

\section{d. Instrumentasi}

Instrumen yang digunakan dalam penelitian in adalah kuesioner. Kuesioner disusun dalam bentuk pertanyaan dengan mengacu kepada hierarki yang telah dibuat dari kriteria-kriteria dan subkriteria-subkriteria berdasarkan skala Saaty 1-9 dengan metode pairwise comparison. Rincian kriteria dalam SPK untuk menentukan mahasiswa berprestasi, sebagai berikut :
a. IPK
b. Karya Tulis
c. Ekstrakulikuler
d. Bahasa Inggris
e. Kepribadian
f. Kegiatan Mahasiswa

e. Solusi Dengan Expert Choice 2000

Penelitian ini dirancang dan dikembangkan dengan metode deskriptif analitik dengan menyajikan rangkuman hasil survey dan wawancara yang berupa kuesioner. Selanjutnya dilakukan pencarian data sekunder yang ada di lapangan melalui berbagai media, seperti internet, buku literatur, jurnal, dan artikel sehingga didapatkan informasi yang akurat mengenai kondisi masyarakat mengenai mahasiswa berprestasi. Kemudian hasil wawancara dengan pakar dijadikan untuk mendapatkan hasil berupa langkah-langkah strategis yang harus dilakukan pada penerapan pemilihan mahasiswa 
berprestasi. Keputusan yang diperoleh segera ditindaklanjuti berupa tindakan atau dapat pula dikaji ulang bila ternyata diperoleh informasi baru yang mempengaruhi hasil untuk mengurangi ketidakpastian, sehingga akan diperoleh keputusan yang baru.

\section{PENGUJIAN DAN PEMBAHASAN}

Metode pemilihan sampel dalam peneilitan ini adalah teknik purpose sampling. Sampel diambil dengan maksud atau tujuan tertentu. Data diambil sebagai sampel karena peneliti menganggap bahwa data tersebut memiliki informasi yang diperlukan bagi penelitiannya. Jumlah sampel yang terpilih ada 3 orang yaitu Pembantu Ketua 1 Bidang Akademik, Pembantu Ketua 3 Bidang Kemahasiswaan dan Ketua Pengurus Yayasan Atma Luhur.

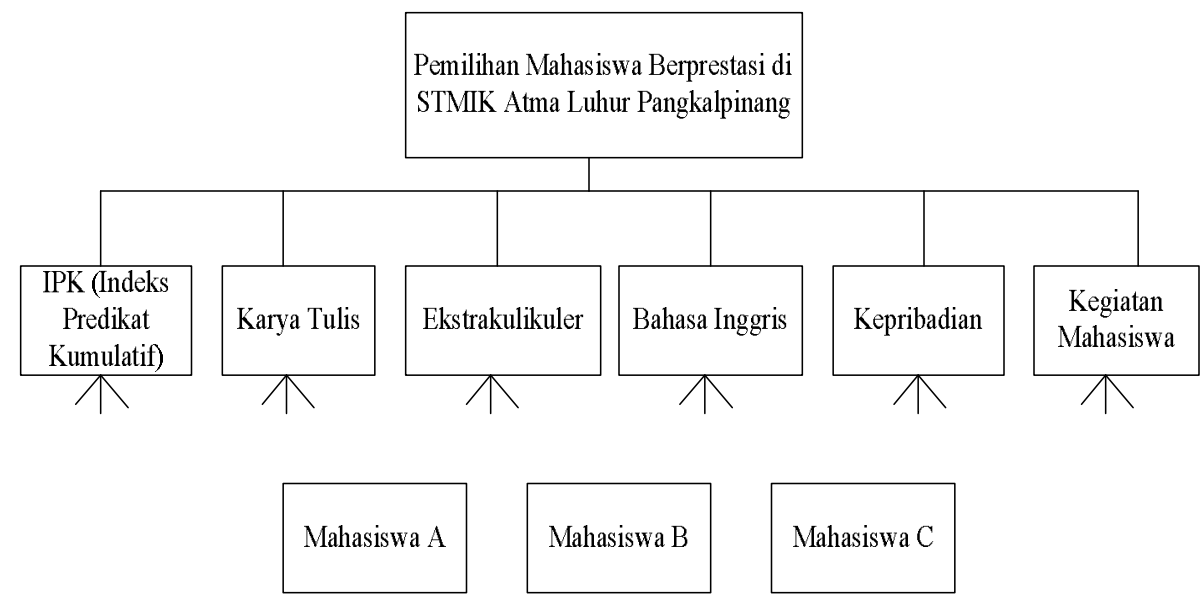

Gambar 2. Struktur hierarki AHP pemilihan mahasiswa berprestasi

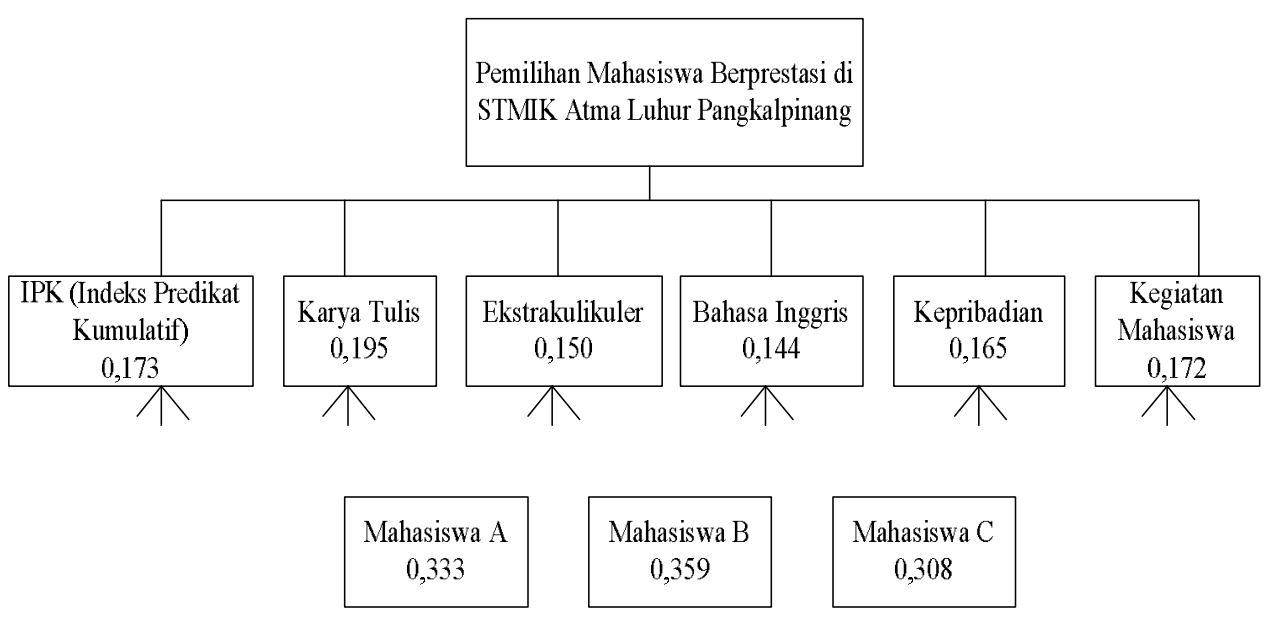

Gambar 3. Struktur hierarki AHP pemilihan mahasiswa berprestasi beserta nilai bobot 
Berikut bobot masing-masing kriteria dan alternatif pemilihan mahasiswa berprestasi

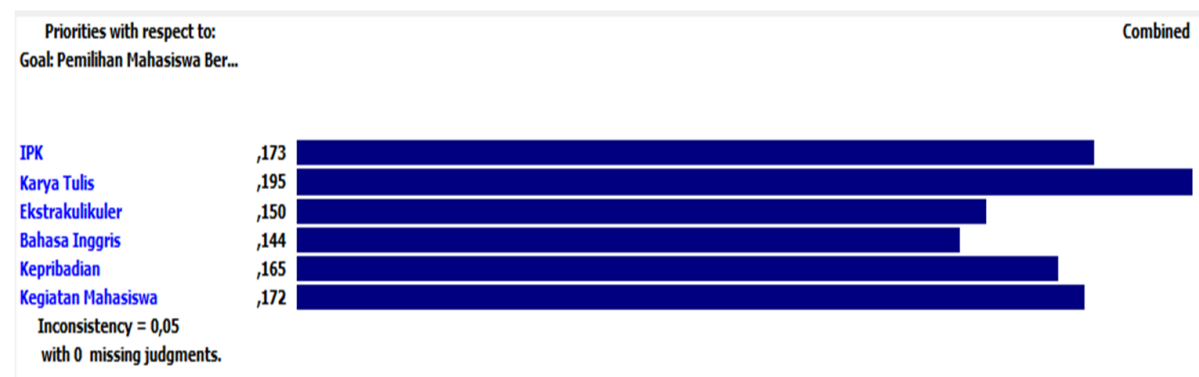

Gambar 4.Kriteria yang harus dipertimbangkan dalam pemilihan mahasiswa berprestasi

Berdasarkan hasil pengolahan data responden ahli diperoleh bahwa prioritas utama atau tertinggi yaitu kriteria karya tulis dengan nilai bobot 0,195 atau sebanding dengan 19,5\% dari total kriteria. Peringkat prioritas kriteria berikutnya adalah tarif dengan nilai bobot 0,173 atau sebnading dengan 17,3\% dari total kriteria. Peringkat prioritas kriteria berikutnya adalah kegiatan mahasiswa dengan nilai bobot 0,172 atau sebanding dengan $17,2 \%$ dari total kriteria. Peringkat prioritas kriteria berikutnya adalah kepribadian dengan nilai bobot 0,165 atau sebanding dengan 16,25\% dari total kriteria. Peringkat prioritas kriteria berikutnya adalah ekstrakulikuler dengan nilai bobot 0,150 atau sebanding dengan 15,0\% dari total kriteria. Peringkat prioritas kriteria yang terakhir adalah bahasa inggris dengan nilai bobot 0,144 atau sebanding dengan $14,4 \%$ dari total kriteria.

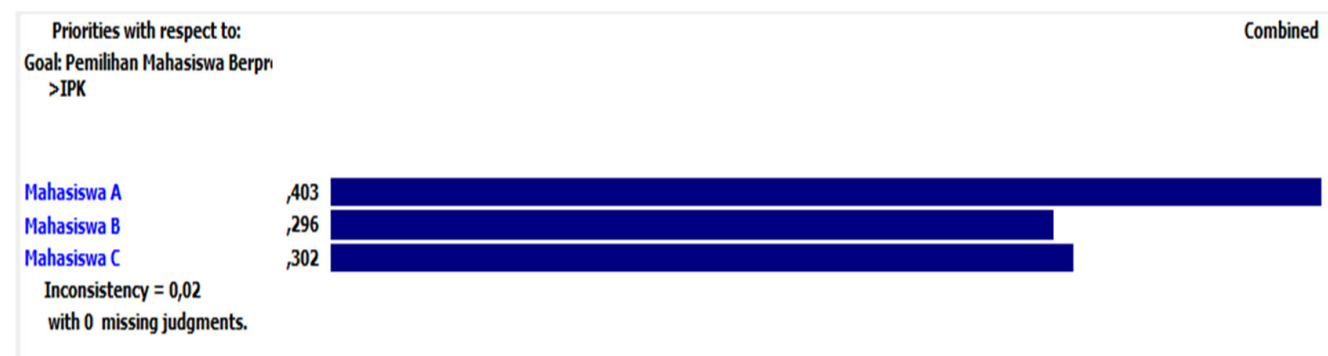

Gambar 5. Alternatif yang harus dipertimbangkan dalam pemilihan mahasiswa berprestasi beserta nilai bobotnya berdasarkan kriteria IPK

Berdasarkan hasil pengolahan data responden ahli diperoleh bahwa prioritas utama atau tertinggi yaitu alternatif mahasiswa A dengan nilai bobot 0,403 atau sebanding dengan 40,3\% dari total alternatif. Peringkat prioritas kriteria berikutnya adalah mahasiswa $\mathrm{C}$ dengan nilai bobot 0,302 atau sebnading dengan 30,2\% dari total alternatif. Peringkat prioritas kriteria berikutnya adalah mahasiswa B dengan nilai bobot 0,296 atau sebanding dengan 29,6\% dari total alternatif.

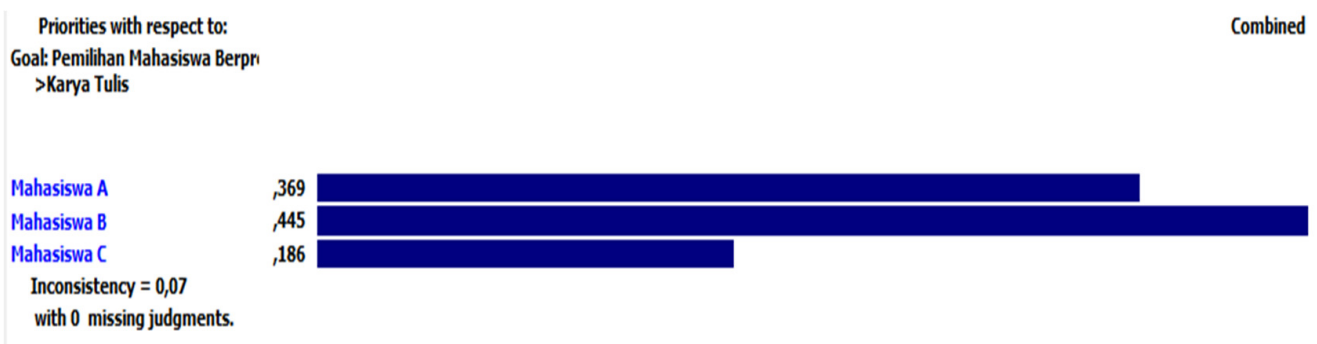

Gambar 6. Alternatif yang harus dipertimbangkan dalam pemilihan mahasiswa berprestasi beserta nilai bobotnya berdasarkan kriteria karya tulis

Berdasarkan hasil pengolahan data responden ahli diperoleh bahwa prioritas utama atau tertinggi yaitu alternatif mahasiswa B dengan nilai bobot 0,445 atau sebanding dengan $44,5 \%$ dari total alternatif. Peringkat prioritas kriteria berikutnya adalah mahasiswa A dengan nilai bobot 0,369 atau sebnading dengan 36,9\% dari total alternatif. Peringkat 
prioritas kriteria berikutnya adalah mahasiswa C dengan nilai bobot 0,186 atau sebanding dengan 18,6\% dari total alternatif.

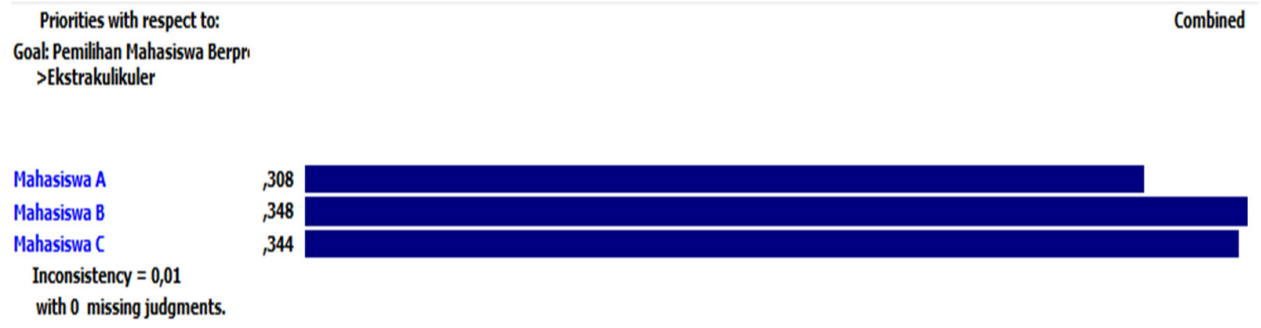

Gambar 7. Alternatif yang harus dipertimbangkan dalam pemilihan mahasiswa berprestasi beserta nilai bobotnya berdasarkan kriteria ekstrakulikuler

Berdasarkan hasil pengolahan data responden ahli diperoleh bahwa prioritas utama atau tertinggi yaitu alternatif mahasiswa $\mathrm{B}$ dengan nilai bobot 0,348 atau sebanding dengan 34,8\% dari total alternatif. Peringkat prioritas kriteria berikutnya adalah mahasiswa $\mathrm{C}$ dengan nilai bobot 0,344 atau sebnading dengan 34,4\% dari total alternatif. Peringkat prioritas kriteria berikutnya adalah mahasiswa A dengan nilai bobot 0,308 atau sebanding dengan 30,8\% dari total alternatif.

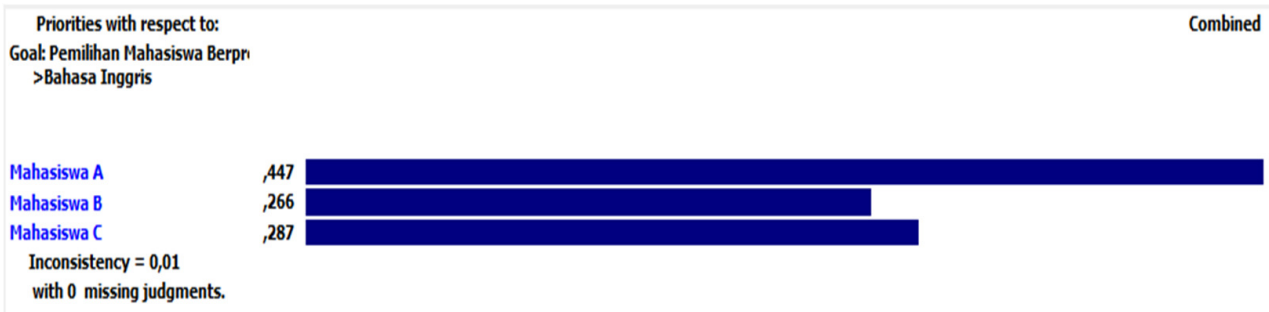

Gambar 8. Alternatif yang harus dipertimbangkan dalam pemilihan mahasiswa berprestasi beserta nilai bobotnya berdasarkan kriteria bahasa inggris

Berdasarkan hasil pengolahan data responden ahli diperoleh bahwa prioritas utama atau tertinggi yaitu alternatif mahasiswa A dengan nilai bobot 0,447 atau sebanding dengan 44,7\% dari total alternatif. Peringkat prioritas kriteria berikutnya adalah mahasiswa $\mathrm{C}$ dengan nilai bobot 0,287 atau sebnading dengan $28,7 \%$ dari total alternatif. Peringkat prioritas kriteria berikutnya adalah mahasiswa B dengan nilai bobot 0,266 atau sebanding dengan $26,6 \%$ dari total alternatif.

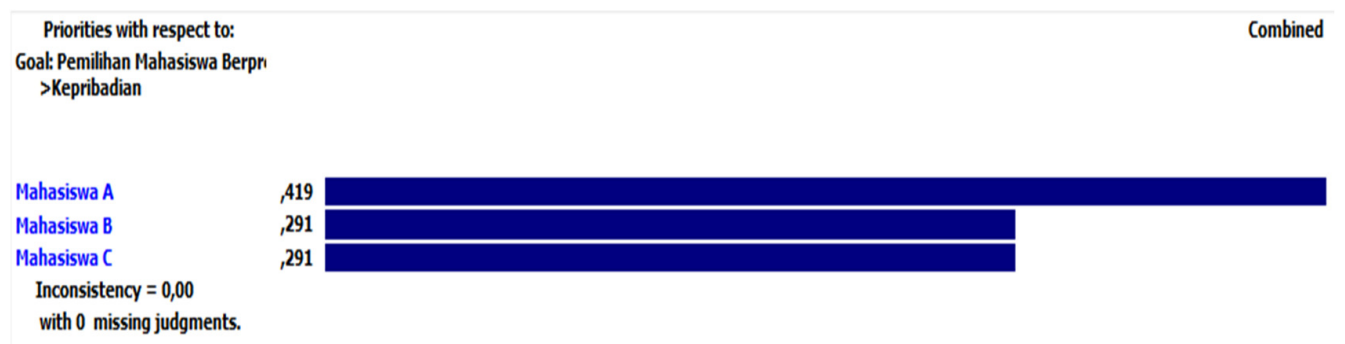

Gambar 9. Alternatif yang harus dipertimbangkan dalam pemilihan mahasiswa berprestasi beserta nilai bobotnya berdasarkan kriteria kepribadian

Berdasarkan hasil pengolahan data responden ahli diperoleh bahwa prioritas utama atau tertinggi yaitu alternatif mahasiswa A dengan nilai bobot 0,419 atau sebanding dengan 41,9\% dari total alternatif. Peringkat prioritas kriteria berikutnya adalah mahasiswa B,C dengan nilai bobot 0,291 atau sebnading dengan 29,1\% dari total alternatif. 


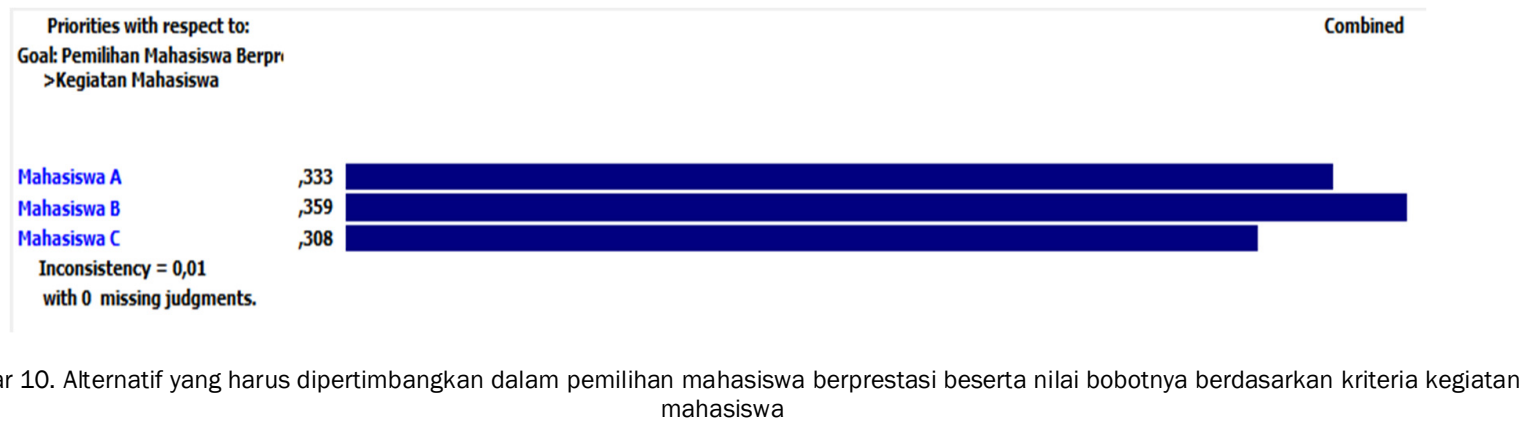

Berdasarkan hasil pengolahan data responden ahli diperoleh bahwa prioritas utama atau tertinggi yaitu alternatif mahasiswa B dengan nilai bobot 0,359 atau sebanding dengan 41,9\% dari total alternatif. Peringkat prioritas kriteria berikutnya adalah mahasiswa A dengan nilai bobot 0,333 atau sebnading dengan 33,3\% dari total alternatif. Peringkat prioritas kriteria berikutnya adalah mahasiswa C dengan nilai bobot 0,308 atau sebnading dengan $30,8 \%$ dari total alternatif.

\section{Synthesis with respect to:}

\section{Goal: Pemilihan Mahasiswa Berprestasi}

Overall Inconsistency $=, 02$

\section{Mahasiswa A \\ Mahasiswa B}

Mahasiswa C

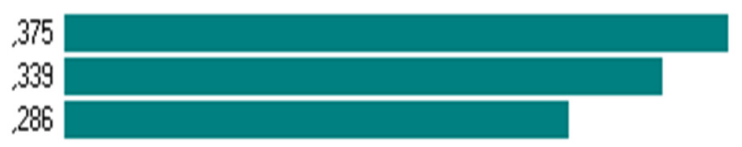

Gambar 11. Nilai Bobot Global Prioritas Alternatif Berdasarkan Pemilihan Mahasiswa Berprestasi di STMIK Atma Luhur Pangkalpinang

Berdasarkan hasil pengolahan data responden ahli diperoleh bahwa prioritas utama atau tertinggi alternative strategis adalah "Mahasiswa A" dengan nilai bobot 0,375 atau sebanding dengan 37,5\% dari total alternative yang ditetapkan. Peringkat prioritas alternative berikutnya adalah "Mahasiswa B" dengan nilai bobot 0,339 atau sebanding dengan 33,9\% dari total alternative yang ditetapkan. Peringkat prioritas alternative manfaat berikutnya adalah "Mahasiswa C" dengan nilai bobot 0,286 atau sebanding dengan $28,6 \%$ dari total alternative yang ditetapkan.

\section{PENUTUP}

\section{a. Kesimpulan}

Penelitian ini menyajikan beberapa kriteria yang disusun dalam hirarki Analytical Hierarchy Process (AHP). Hasil pengolahan data dengan Expert Choice menunjukkan bahwa kriteria yang paling penting secara berturut-turut menurut responden ahli adalah karya tulis 19,5\%, IPK 17,3\%, Kegiatan mahasiswa 17,2\% dan Kepribadian 16,5\%, Ekstrakulikuler $15,0 \%$, Bahasa Inggris 14,4\%. Sedangkan alternatif yang paling penting secara berturut-turut menurut responden ahli adalah Mahasiswa A 37,9\%, Mahasiswa B 33,9\% dan Mahasiswa C 28,2\%.

\section{b. Saran}

Harus disadari penelitian yang dilakukan oleh peneliti banyak sekali kekurangan, untuk itu peneliti mengajukan saran agar peneliti selanjutnya dapat meneruskan penelitian ini dengan menggunakan metode yang sama atau bisa menggunakan metode yang berbeda agar diperoleh hasil yang maksimal. 


\section{REFERENSI}

[1] Expert Choice inc Pennsyil Vania, 1992, Version 8.0 User Manual.

[2] Saaty, T.L., 1993, Fundamental of Decision Making and Priority Theory with the Analytical Hierarchy Process, RWS Puclications, Pittsburgh PA.

[3] Turban, E; Jay E.A, 1998, Decision Support System and Intelligent System, Fifth Edition, Prentice Hall International, Inev. New Jersey

[4] https://ahmadnasikun.wordpress.com diakses tanggal 24 Mei 2016 